\title{
Article \\ Sex Differences on Mitotane Concentration and Treatment Outcome in Patients with Adrenocortical Carcinoma
}

\author{
Sarah Allegra ${ }^{1, *} \mathbb{B}$, Soraya Puglisi ${ }^{2}\left(\mathbb{D}\right.$, Irene Brescia ${ }^{1}$, Francesco Chiara ${ }^{1}$, Vittoria Basile ${ }^{2}$, Anna Calabrese ${ }^{2}$, \\ Giuseppe Reimondo ${ }^{2}(1)$ and Silvia De Francia ${ }^{1}$ \\ 1 Laboratory of Clinical Pharmacology "Franco Ghezzo", Department of Clinical and Biological Sciences, \\ University of Turin, S. Luigi Gonzaga Hospital, 10043 Orbassano, TO, Italy; irene.brescia@edu.unito.it (I.B.); \\ 336124@edu.unito.it (F.C.); silvia.defrancia@unito.it (S.D.F.) \\ 2 Internal Medicine, Department of Clinical and Biological Sciences, University of Turin, \\ S. Luigi Gonzaga Hospital, 10043 Orbassano, TO, Italy; soraya.puglisi@unito.it (S.P.); \\ basile_vittoria@libero.it (V.B.); anna.calabrese@unito.it (A.C.); giuseppe.reimondo@unito.it (G.R.) \\ * Correspondence: sarah.allegra@unito.it; Tel.: +39-011-6705442
}

check for updates

Citation: Allegra, S.; Puglisi, S.; Brescia, I.; Chiara, F.; Basile, V.; Calabrese, A.; Reimondo, G.; De Francia, S. Sex Differences on Mitotane Concentration and Treatment Outcome in Patients with Adrenocortical Carcinoma. Life 2021, 11, 266. https://doi.org/10.3390/ life11030266

Academic Editor: Paola Nieri

Received: 24 February 2021

Accepted: 19 March 2021

Published: 23 March 2021

Publisher's Note: MDPI stays neutral with regard to jurisdictional claims in published maps and institutional affiliations.

Copyright: (c) 2021 by the authors. Licensee MDPI, Basel, Switzerland. This article is an open access article distributed under the terms and conditions of the Creative Commons Attribution (CC BY) license (https:// creativecommons.org/licenses/by/ $4.0 /)$.

\begin{abstract}
Background: In clinical settings, data regarding sex are rarely investigated. In women, factors such as body size and composition, hormonal variations, metabolism, and access to care systems and therapy could strongly influence the pharmacological management and the outcome of the therapy. To underline this sex-related difference, we retrospectively collected data from adrenocortical carcinoma patients treated with mitotane, and then evaluated sex-related pharmacokinetics parameters. (2) Methods: A fully validated chromatographic method was used to quantify mitotane concentration in plasma collected from adult patients, also considering the active metabolite ortho,para,dichlorodiphenylethene (o, $\mathrm{p}^{\prime}$-DDE). Statistical analyses were used to evaluate the sex influence on drugs pharmacokinetics. (3) Results: We found that sex resulted as predictive factor of plasma mitotane and $o, p^{\prime}$-DDE concentrations and significantly influenced the attainment of the therapeutic target of mitotane, implying that female sex could be a risk factor of treatment failure. (4) Conclusions: These results suggest that mitotane therapy should be modulated according to patient sex. Furthermore, the proposed approach could contribute to facilitating and disseminating sex-specific pharmacology.
\end{abstract}

Keywords: AAC; o,p'-DDD; o, $\mathrm{p}^{\prime}$-DDE; TDM; gender

\section{Introduction}

Adrenocortical carcinoma (ACC) is a rare neoplasm originating in the cortex of the adrenal gland [1]. The prognosis of ACC is unfavorable and surgery remains the only curative treatment [2]. Unfortunately, even in patients undergoing a complete surgical excision, locoregional recurrence or distant metastases occur in most cases [3]. Adjuvant treatment with mitotane is useful to reduce the recurrence rate in high-risk patients [4,5]. Mitotane, alone or in combination with other drugs, is also recommended in metastatic or unresectable diseases $[3,6]$.

Mitotane (ortho,para,dichlorodiphenyl dichloroethane, o, p'-DDD, 2,2-bis[2-chlorophenyl4-chlorophenyll-1,1-dichloroethane) is an adrenolytic drug derived from the insecticide dichlorodiphenyltrichloroethane, which has been used in treatment centers since 1959 [7]. Mitotane and its two active metabolites, o, $\mathrm{p}^{\prime}$-DDE (dichlorodiphenylethene) and o, $\mathrm{p}^{\prime}$-DDA (dichlorodiphenylacetate), have different mechanisms of actions: they act as antineoplastic agents, through the production of free radicals mediating cytotoxicity, and as inhibitors of adrenocortical steroidogenesis, blocking the cholesterol side-chain cleavage enzymes cytochrome P450 (CYP) 11A1 and 11B [8]. Therefore, mitotane and its metabolites can ameliorate signs and symptoms of cortisol excess in secreting ACC [9].

Mitotane therapeutic drug monitoring (TDM) is recommended to optimize the benefit and avoid adverse events [6,10]. Plasma mitotane concentrations between 14 and $20 \mathrm{mg} / \mathrm{L}$ 
are considered as the target range, because concentrations $>14 \mathrm{mg} / \mathrm{L}$ have been associated with improved outcomes; central neurologic toxicity is more frequent with mitotane concentrations $>20 \mathrm{mg} / \mathrm{L}$ [11-13].

As previously reported, mitotane bioavailability could depend on different factors, such as drug dose, sex, genetics, season in which the drug is administered, and drug-drug interaction [5,14-18].

Sex-related differences in drug pharmacodynamics and pharmacokinetics, response to treatment, and related toxicity have been only partially reported. In a recent study from our group, the female sex was associated with a lower mitotane dose when the drug was used as an adjuvant measure. This is not surprising since data regarding sex-related differences are rarely investigated in clinics [19]. In women, factors such as body size and composition, hormonal variations, metabolism, and access to health care systems and therapy could strongly influence the pharmacological management and treatment outcomes. To this purpose, we described the sex-related differences in a cohort of ACC patients treated with adjuvant mitotane.

\section{Materials and Methods}

\subsection{Patients and Inclusion Criteria}

We performed a retrospective cohort study in ACC patients treated at the S. Luigi Hospital. All patients underwent radical surgery for ACC and then started mitotane as an adjuvant treatment. Inclusion criteria were: age $\geq 18$ years, histologically confirmed diagnosis of ACC according to Weiss score [20], ENSAT stage I-III at diagnosis, complete tumor resection, defined as R0, R1 or RX resection on the basis of surgical and pathologic reports, availability of postoperative follow-up information, and regular quantification of plasma mitotane concentration. Exclusion criteria were: macroscopically incomplete resection, incomplete tumor staging, concomitant cancers within the previous 5 years except for non-melanoma skin cancer treated radically, clinically significant concomitant disease, incomplete follow-up information or follow-up duration of less than 6 months, initiation of mitotane treatment longer than 6 months after surgery, and concomitant postoperative adjuvant therapies (chemotherapy or radiotherapy). Mitotane formulation was Lysodren ${ }^{\circledR}$, $500 \mathrm{mg}$ tablets (Laboratoire HRA Pharma, Paris, France). Mitotane was administered following a low-dose protocol: starting dose of $1 \mathrm{~g}$ daily, with increase every 4-7 days, up to 8-10 g daily or the maximum tolerated dose [21]. Collected data were age, sex, date of diagnosis, imaging data, ACC stage, clinical presentation including assessment of hormone secretion, type of surgery, pathology report, adjuvant treatment, date and type of recurrence, treatment of recurrence, and last follow-up or death. Date of diagnosis was defined as the date of surgery and conversion to open adrenalectomy was considered open surgery. Completeness of surgery was established by $\mathrm{R}$ status: $\mathrm{R} 0$, free resected margins; R1, microscopic involvement of resected margins; RX, not determined, and R2, macroscopic invasion of resected margins. Tumor stage was established according to the ENSAT classification (I-II, confined tumor; III, positive lymph nodes or infiltrating neighboring organs/veins without distant metastases; IV, distant metastases [22]). Biochemical confirmation of hormone excess was requested to categorize an ACC as hormone secreting, information was available only for 238 patients. Patients were stratified for Ki67 index (Ki67 $\leq 10 \%$ and $\mathrm{Ki} 67>10 \%$ ). Date of recurrence was defined as the date of radiological evidence of a new lesion. Recurrence-free survival (RFS) was calculated from the time of initial surgery to the first radiological evidence of recurrence (in months). Overall survival (OS) was calculated from the date of initial surgery to the date of death (in months). The study protocol ("Pharmacogenetic determinants mitotane pharmacokinetics") was approved by the local Ethics Committee. Written informed consent for the study was obtained from each enrolled subject. 


\subsection{HPLC Analysis}

Plasma $o, p^{\prime}$-DDD and $o, p^{\prime}$-DDE concentrations were determined from blood samples obtained at the end of dosing interval, before the next drug dose intake. Considering $\mathrm{o}, \mathrm{p}^{\prime}$-DDE concentrations, the quantification was inserted in the study after a protocol revision; thus, this information was not available for all the enrolled patients.

Patient blood samples were collected in the lithium-heparin tube and centrifuged at $1500 \mathrm{rpm}$ for $10 \mathrm{~min}$ at $4{ }^{\circ} \mathrm{C}$. Analytes quantification was performed by a validated high performance liquid chromatography method coupled with UV detection (HPLC-UV) [23]. Substances separation, after specific liquid extraction, was achieved on a RP-C18 column. Internal standard quantification was used, fitted with linear regression.

\subsection{Statistical Analysis}

For descriptive statistics, continuous and non-normal variables were summarized as median values (considering all the enrolled patients) and the interquartile range (IQR, quartile 1; quartile 3) was calculated to measure the statistical dispersion of the data; categorical variables were described as frequency and percentage. All the variables were tested for normality with the Shapiro-Wilk test. The correspondence of each parameter was evaluated with a normal or non-normal distribution through the Kolmogorov-Smirnov test. Non-normal variables were described by median values (plasma concentration). The Mann-Whitney test was used to compare plasma concentration and sex (level of statistical significance $p$-value $<0.05$ ). Any predictive power of the considered variables was finally evaluated through univariate and multivariate linear ( $\beta$ coefficient) for continuous variables, and logistic (OR, odd ratio), considering therapeutic range, regression analyses (IC, interval of confidence at 95\%). Factors with $p$-value $<0.2$ in univariate analysis were considered in multivariate analysis (level of statistical significance $p$-value $<0.05$ ). Survival curves for RFS and OS were computed according to the Kaplan-Meier method and were compared by means of the log-rank test. All tests were performed with IBM SPSS Statistics 22.0 per Windows (Chicago, IL, USA).

\section{Results}

\subsection{Study Population}

We retrieved data from $246 \mathrm{ACC}$ patients. The o, $\mathrm{p}^{\prime}$-DDE concentration was determined in 178 samples. Baseline characteristics of our cohort are given in Table 1.

Table 1. Demographic, clinical, and pharmacokinetic characteristics of the enrolled patients.

\begin{tabular}{cc}
\hline Variable & $\mathbf{N}=\mathbf{2 4 6}$ \\
\hline Male, $\mathrm{n}(\%)$ & $147(59.8)$ \\
\hline Female, $\mathrm{n}(\%)$ & $99(40.2)$ \\
\hline Median age, years (IQR) & $45.5(35.2-57.1)$ \\
\hline Median body mass index (BMI), kg $/ \mathrm{m}^{2}(\mathrm{IQR})$ & $23.4(21.6-27.5)$ \\
\hline Margins, R status & \\
R0, $\mathrm{n}(\%)$ & $89(36.8)$ \\
R1, $\mathrm{n}(\%)$ & $57(23.6)$ \\
RX, $\mathrm{n}(\%)$ & $8(3.3)$ \\
\hline Median size, cm (IQR) & $7.00(1.00-12.00)$ \\
\hline Median Ki67 index, \% (IQR) & $25.50(14.00-40.00)$ \\
\hline Median mitotic count (IQR) & $12.50(6.00-25.00)$ \\
Tumor stage & $16(6.6)$ \\
I, $\mathrm{n}(\%)$ & $82(33.9)$ \\
II, n (\%) & $38(15.7)$ \\
III, n (\%) & $28(11.6)$ \\
IV, n (\%) &
\end{tabular}


Table 1. Cont.

\begin{tabular}{|c|c|}
\hline Variable & $N=246$ \\
\hline \multicolumn{2}{|l|}{ Hormone secretion } \\
\hline No secretion, $\mathrm{n}(\%)$ & $73(30.2)$ \\
\hline Secretion, n (\%) & $82(33.9)$ \\
\hline Cortisol/cortisol + other steroids, n (\%) & $66(27.3)$ \\
\hline No hormone work up, $\mathrm{n}(\%)$ & $17(7.0)$ \\
\hline Median Weiss score (IQR) & $7(5-8)$ \\
\hline Death, n (\%) & $83(34.3)$ \\
\hline Median recurrence-free survival, months (IQR) & $19.00(7.00-69.00)$ \\
\hline Median overall survival, months (IQR) & $60.50(28.25-100.75)$ \\
\hline Median o,p'-DDD concentration, $\mu \mathrm{g} / \mathrm{mL}$ (IQR) & $8.82(4.36-14.37)$ \\
\hline $\begin{array}{l}\text { Median } \mathrm{o}, \mathrm{p}^{\prime} \text {-DDE concentration, } \mu \mathrm{g} / \mathrm{mL} \text { (IQR) } \\
(\mathrm{N}=178)\end{array}$ & $0.90(0.48-1.50)$ \\
\hline \multicolumn{2}{|l|}{ Mitotane therapeutic range } \\
\hline$<14 \mu \mathrm{g} / \mathrm{mL}$ & $180(73.2)$ \\
\hline $14-20 \mu \mathrm{g} / \mathrm{mL}$ & $50(20.3)$ \\
\hline$>20 \mu \mathrm{g} / \mathrm{mL}$ & $16(6.5)$ \\
\hline
\end{tabular}

$\overline{\mathrm{N}}$, number; IQR, interquartile range; BMI, body mass index; Ctrough, concentration at the end of dosing interval; $\%$, percentage.

\subsection{Effect of Sex on Plasma o, $p^{\prime}-D D D$ Concentrations}

A significant influence of sex on o, $\mathrm{p}^{\prime}$-DDD levels was apparent since levels were lower in females $(\mathrm{N}=147)$ than males $(\mathrm{N}=99)(7.604 \mu \mathrm{g} / \mathrm{mL}(\mathrm{IQR} 3.971-12.353 \mu \mathrm{g} / \mathrm{mL})$ vs. $11.029 \mu \mathrm{g} / \mathrm{mL}$ (IQR 5.052-15.779 $\mu \mathrm{g} / \mathrm{mL}$ ), $p=0.007$, Figure 1). In a linear regression analysis, sex and hormone secretion were predictive factors (Table 2).

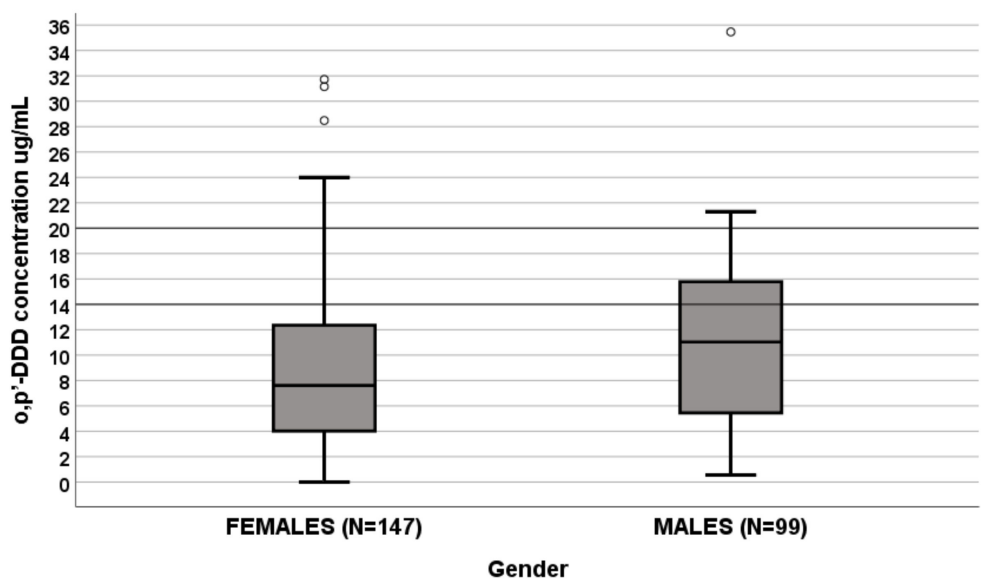

Figure 1. Influence of gender on ortho,para,dichlorodiphenyl dichloroethane (o, $\mathrm{p}^{\prime}$-DDD) plasma concentrations $(\mu \mathrm{g} / \mathrm{mL})$.

The box plot of gender influence on o, $\mathrm{p}^{\prime}$-DDD plasma concentrations at the end of dosing interval $(\mu \mathrm{g} / \mathrm{mL})$; boxes and black lines in boxes represent respectively interquartile ranges (IQR) and median values; open dots and stars represent outlier values. Median values (horizontal line), IQR (bars), patient values (black square), highest and lowest value (whiskers), and $p$ value are shown.

- $\quad$ Females ( $\mathrm{N}=147$ ): median o,p'-DDD of $7.604 \mu \mathrm{g} / \mathrm{mL}(\mathrm{IQR} 3.971-12.353 \mu \mathrm{g} / \mathrm{mL}$ );

- $\quad$ Males ( $\mathrm{N}$ = 99): median o,p'-DDD $11.029 \mu \mathrm{g} / \mathrm{mL}$ (IQR 5.052-15.779 $\mu \mathrm{g} / \mathrm{mL}$ ). 


\subsection{Effect of Sex on Plasma o, $p^{\prime}$-DDE Concentrations}

The o, $\mathrm{p}^{\prime}$-DDE levels were significantly influenced by sex since females $(\mathrm{N}=102)$ had lower values than males $(\mathrm{N}=75)(0.373 \mu \mathrm{g} / \mathrm{mL}$ (IQR $0-1 \mu \mathrm{g} / \mathrm{mL})$ vs. $0.823 \mu \mathrm{g} / \mathrm{mL}$ (IQR $0.21-1.5 \mu \mathrm{g} / \mathrm{mL}$ ), $p=0.002$, Figure 2). In a linear regression, age and sex resulted as predictive factors of $\mathrm{o}, \mathrm{p}^{\prime}$-DDE levels (Table 2). Section 3.1.

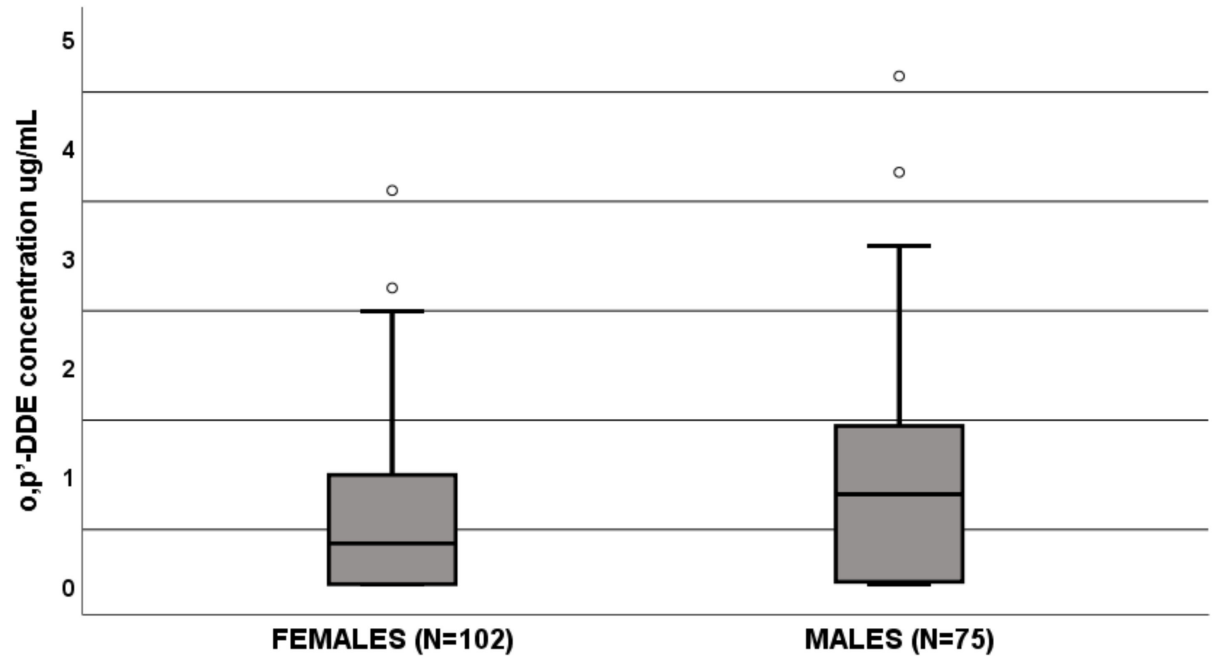

Figure 2. Influence of gender on ortho,para,dichlorodiphenyl dichloroethane (o, $\mathrm{p}^{\prime}$-DDE) plasma concentrations $(\mu \mathrm{g} / \mathrm{mL})$.

Table 2. Factors, in univariate and multivariate linear regression analyses, able to predict o, $\mathrm{p}^{\prime}$-DDD and o, $\mathrm{p}^{\prime}$-DDE concentrations.

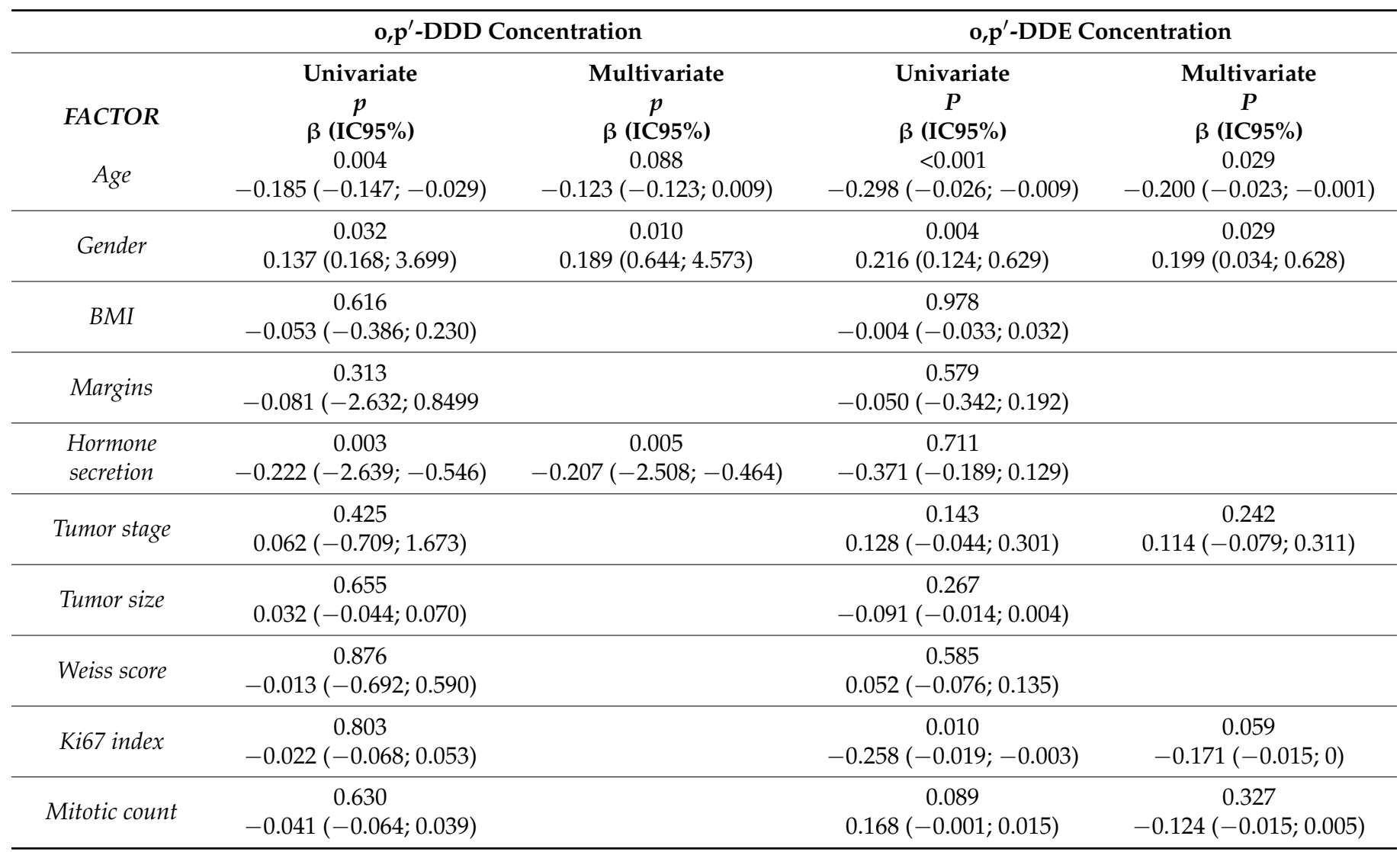


The box plot of gender influence on o, $\mathrm{p}^{\prime}$-DDE plasma concentrations at the end of dosing interval $(\mu \mathrm{g} / \mathrm{mL})$; boxes and black lines in boxes represent respectively interquartile ranges (IQR) and median values; open dots and stars represent outlier values. Median values (horizontal line), IQR (bars), patient values (black square), highest and lowest value (whiskers) and $p$ value are shown.

- Females ( $\mathrm{N}=102)$ : median o, $\mathrm{p}^{\prime}$-DDE of $0.373 \mu \mathrm{g} / \mathrm{mL}(\mathrm{IQR} 0-1 \mu \mathrm{g} / \mathrm{mL})$;

- Males ( $=75$ ): median o,p'-DDE $0.823 \mu \mathrm{g} / \mathrm{mL}(\mathrm{IQR} 0.21-1.5 \mu \mathrm{g} / \mathrm{mL}$ ).

\subsection{Effect of Sex on Mitotane Concentration Therapeutic Range}

In a logistic regression analysis, sex and hormone secretion were mitotane therapeutic range predictive factors (values $>14 \mu \mathrm{g} / \mathrm{mL}$ and $<20 \mu \mathrm{g} / \mathrm{mL}$; Table 3). Figure 3 shows the distribution of males and females based on therapeutic range.

Table 3. Factors, in univariate and multivariate logistic regression analyses, able to predict mitotane concentration therapeutic range.

\begin{tabular}{|c|c|c|}
\hline & UNIVARIATE & MULTIVARIATE \\
\hline FACTOR & $\begin{array}{c}p \\
\text { OR (IC95\%) }\end{array}$ & $\begin{array}{c}p \\
\text { OR (IC95\%) }\end{array}$ \\
\hline Age & $\begin{array}{c}0.407 \\
0.991(0.970 ; 1.012)\end{array}$ & \\
\hline Gender & $\begin{array}{c}0.001 \\
0.326(0.171 ; 0.619)\end{array}$ & $\begin{array}{c}<0.001 \\
4.829(2.156 ; 10.814)\end{array}$ \\
\hline BMI & $\begin{array}{c}0.709 \\
0.977(0.865 ; 1.104)\end{array}$ & \\
\hline Margins & $\begin{array}{c}0.693 \\
1.154(0.635 ; 2.095)\end{array}$ & \\
\hline Hormone secretion & $\begin{array}{c}0.001 \\
0.422(0.249 ; 0.716) \\
\end{array}$ & $\begin{array}{c}0.005 \\
0.484(0.292 ; 0.801) \\
\end{array}$ \\
\hline Tumour stage & $\begin{array}{c}0.100 \\
0.699(0.455 ; 1.072)\end{array}$ & $\begin{array}{c}0.102 \\
0.663(0.405 ; 1.085)\end{array}$ \\
\hline Tumour size & $\begin{array}{c}0.188 \\
1.011(0.994 ; 1.029)\end{array}$ & $\begin{array}{c}0.728 \\
0.996(0.976 ; 1.017) \\
\end{array}$ \\
\hline Weiss score & $\begin{array}{c}0.925 \\
0.990(0.799 ; 1.227) \\
\end{array}$ & \\
\hline Ki67 index & $\begin{array}{c}0.219 \\
0.987(0.967 ; 1.008) \\
\end{array}$ & \\
\hline Mitotic count & $\begin{array}{c}0.387 \\
0.992(0.974 ; 1.010)\end{array}$ & \\
\hline
\end{tabular}

p: $p$ value; OR: odds ratio; IC95\%: interval of confidence at $95 \%$.

\subsection{Effect of Sex on Recurrence Free and Overall Survival}

Estimated RFS ( $p=0.253$, Figure 4$)$ and OS ( $p=0.457$, Figure 5$)$ of the two groups by Kaplan-Meier analysis were not different. For RFS, in females, the standard error was 21.448 with a median value of 71 (IC95\% 28.90; 113.10); in males, the standard error was 4.146 with a median value of 51 (IC95\% 42.87; 59.13). For OS, in females, the standard error was 9.908 and median value of 43 (IC95\% 23.58; 62.42); in males, the standard error was 13.946 with a median value of 55 (IC95\% 27.67; 82.33). 


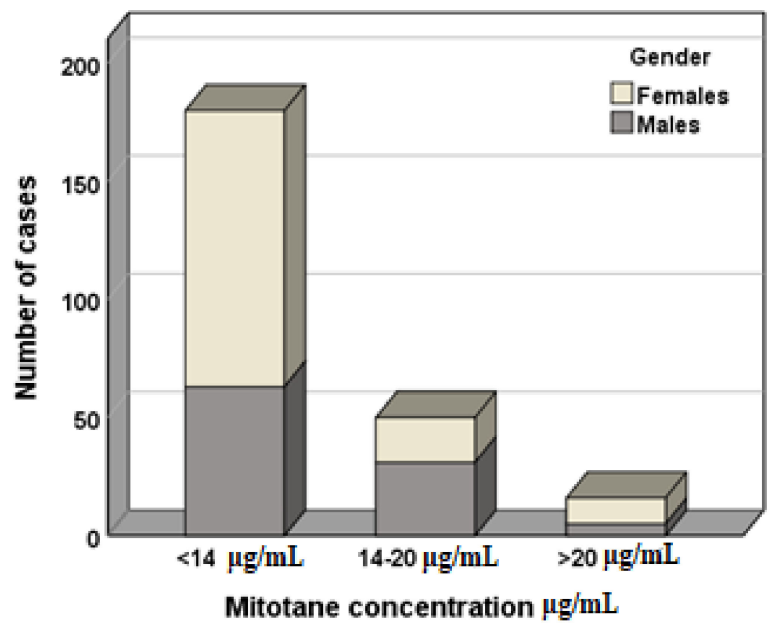

Figure 3. Comparison of gender distribution considering mitotane therapeutic range. $<14 \mu \mathrm{g} / \mathrm{mL}$ : females $\mathrm{N}=117$, males $\mathrm{N}=63 ; 14-20 \mu \mathrm{g} / \mathrm{mL}$ : females $\mathrm{N}=19$, males $\mathrm{N}=31 ;>20 \mu \mathrm{g} / \mathrm{mL}$ : females $\mathrm{N}=11$, males $\mathrm{N}=5$.

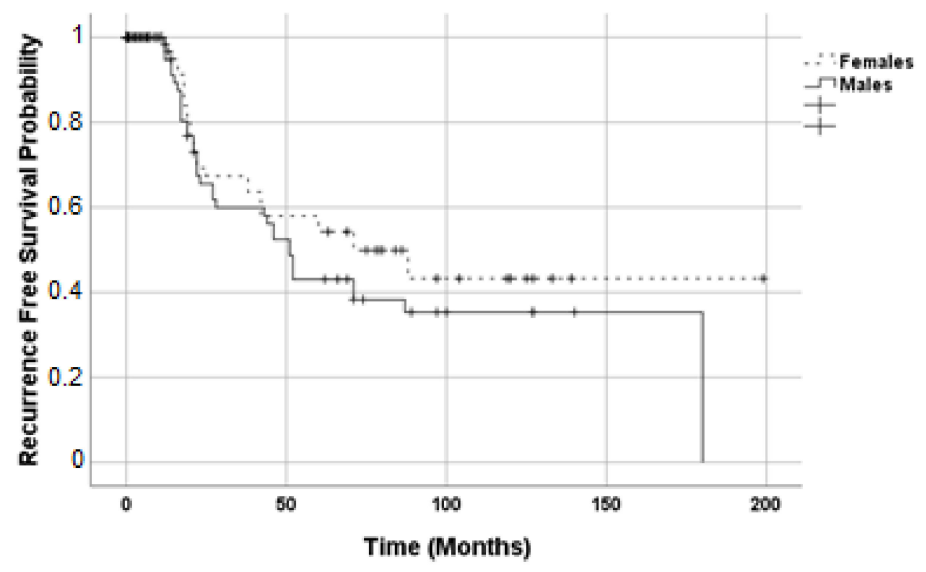

Figure 4. Kaplan-Meier estimates for recurrence-free survival during adjuvant mitotane therapy. Dashed line, female patients $(\mathrm{N}=147)$; solid line, male patients $(\mathrm{N}=99)$.

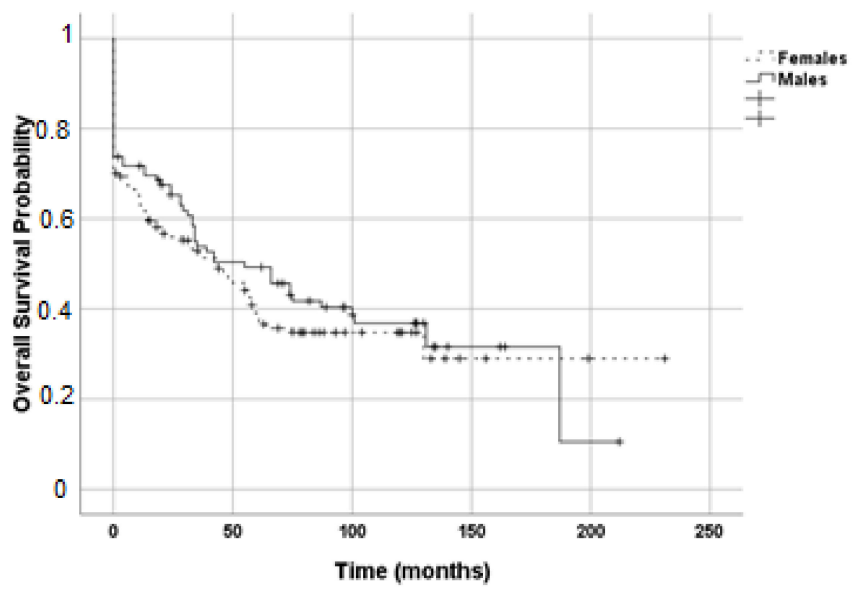

Figure 5. Kaplan-Meier estimates for overall survival during adjuvant mitotane therapy. Dashed line, female patients $(\mathrm{N}=147)$; solid line, male patients $(\mathrm{N}=99)$. 


\section{Discussion}

To date, there is still a large knowledge gap in the field of sex differences in clinical pharmacology. The inclusion of female animals and women in pharmacological studies is still limited, also considering the analysis on safety profile and treatment outcome. However, in the last decade, sex-based significant differences in drug pharmacokinetics and pharmacodynamics have been reported. In particular, males and females differ in drug absorption, distribution, metabolism, clearance, outcome, and toxicity risk [19]. The available evidence suggests that these sex divergences could be due to different factors. For example, hormones influence gastrointestinal motility, thereby drug absorption, and plasma protein levels, altering drug protein binding. During the luteal phase, the high progesterone levels relax the smooth muscle and increase the small intestine retention time, altering drug absorption [19]. The increase of $\alpha-1$ acid glycoprotein levels alters protein binding and, consequently, free drug concentration, volume of distribution, and half-life $[24,25]$. Hormone fluctuations throughout the menstrual cycle can also influence hepatic enzyme activity and, thus, drugs metabolism. Progesterone and estrogens, in contrast to androgens, inhibit liver microsomal enzymes. However, progesterone is also a hepatic enzyme activity enhancer [25-27]. Eventually, CYP3A4 CYP2A6, and CYP2B6 show a higher activity in women, compared to men; instead, for CYP1A2, CYP2E1, and UDP-glucuronosyltransferase (UGT), a female sex-related activity reduction has been reported [28]. Considering body weight differences, this could influence drug dosage, volume of distribution, and clearance. Moreover, women showed a higher body fat percentage and reduced glomerular filtration rate, affecting drug elimination.

This is the first study that investigated the possible influence of sex on mitotane plasma concentration. We found that sex was as predictive factor of $\mathrm{o}, \mathrm{p}^{\prime}-\mathrm{DDD}$ and $\mathrm{o}, \mathrm{p}^{\prime}-\mathrm{DDE}$ concentrations and significantly influenced the achieving of the target plasma mitotane therapeutic range, implying that female sex could be a risk factor for treatment failure. Particularly, we found that more women show mitotane levels under therapeutic range (females $\mathrm{N}=117,80 \%$; males $\mathrm{N}=63,64 \%$ ) and less female patients reach and maintain mitotane levels in this range (females $\mathrm{N}=19,13 \%$; males $\mathrm{N}=31,31 \%$ ). Furthermore, more women showed potentially toxic drug levels (females $\mathrm{N}=11,8 \%$; males $\mathrm{N}=5,5 \%$ ). We hypothesized that this could be due to sex differences in cytochrome P450-mediated metabolism, sexual hormone influence on drug absorption and differences of fat percentage in body composition. However, no difference between females and males has been reported for RFS and OS time with the survival functions. Unfortunately, our research is limited by the lack of data regarding females' hormonal phase and impedance analysis, not available in a retrospective study. The influence of sex in tumorigenesis and prognosis of ACC has been previously investigated. Keskin and colleagues, in 2013, carried out a study on 24 ACC patients (10 females and 14 males) and observed that sex is a prognostic factor: considering overall survival, males (58 months) had a survival advantage over females (12 months) [29]. With respect to genetic predisposition, both in adults and in the pediatric population, there is a predilection for females [30-32]. Recently, Rehane et al. reported a potential sex effect in ACC: mutations in DGKZ, GOLGA4, and NOS3 genes were more frequent in women, with female to male occurrence ratios from 3:1 to 4:0 [33]. In addition, at diagnosis, the mean age was significantly lower in women, possibly due to the consequence of the role of estrogens in adrenal tumorigenesis. The suggested reasons consist in the enhancer role of $17 \beta$-estradiol on adrenocortical cell proliferation, in the increased estrogen-related receptor $\alpha$ expression in cancer tissues and insulin-like growth factor 2 stimulation of ACC cell proliferation [34-37]. Although these studies focused the topic of sex difference in ACC patients, no data were available regarding the impact of sex on plasma mitotane levels. This is a relevant issue, considering the prognostic value of the achieving of the therapeutic mitotane range [11-13]. The strengths of our analysis are the large simple size and the monocentric cohort, which offer the advantage to evaluate patients treated with the same protocol of drug administration, thus avoiding a relevant bias. 
As is already known, age is one of the best predictors of survival [38,39]: older patients have lower survival rates. In this context, lower active metabolite concentrations have been reported in elderly patients.

We also found reduced $o, p^{\prime}$-DDD concentrations and a reduced probability of obtaining therapeutic levels in patients whose tumor had no cortisol secretion. This could be due to the association between hormone secretion and transcriptome signature, as reported in aggressive ACC [40]. Calabrese et al. also observed that secreting tumors were more frequent in younger patients and in women [5], confirming the disadvantage for female ACC patients.

\section{Conclusions}

In conclusion, the results obtained from this retrospective analysis highlight the potential need for sex-specific dosing regimens, to ensure the achievement of therapeutic range. However, no differences in treatment outcome were observed in our cohort. Further and prospective studies, including data about the females' hormonal phases, fat percentage distribution, lipid parameters, and concomitant drugs, are needed to confirm the role of sex in ACC treatment.

Author Contributions: Conceptualization, S.A. and S.D.F.; methodology, S.P.; validation, S.A., G.R., and S.D.F.; formal analysis, I.B. and F.C.; investigation, V.B.; resources, A.C.; data curation, S.A., S.P., and A.C.; writing—original draft preparation, S.A.; writing—review and editing, S.P. and S.D.F.; visualization, G.R.; supervision, S.D.F.; project administration, S.D.F. All authors have read and agreed to the published version of the manuscript.

Funding: This research received no external funding.

Institutional Review Board Statement: The study was conducted according to the guidelines of the Declaration of Helsinki, and approved by the Ethics Committee of San Luigi Gonzaga University Hospital (Pharmacogenetic determinants mitotane pharmacokinetics).

Informed Consent Statement: Informed consent was obtained from all subjects involved in the study.

Conflicts of Interest: The funders had no role in the design of the study; in the collection, analyses, or interpretation of data; in the writing of the manuscript, or in the decision to publish the results.

\section{References}

1. Libé, R. Adrenocortical carcinoma (ACC): Diagnosis, prognosis, and treatment. Front. Cell Dev. Biol. 2015, 3, 45. [CrossRef] [PubMed]

2. Gaujoux, S.; Weinandt, M.; Bonnet, S.; Reslinger, V.; Bertherat, J.; Dousset, B. Surgical treatment of adrenal carcinoma. J. Visc. Surg. 2017, 154, 335-343. [CrossRef] [PubMed]

3. Fassnacht, M.; Dekkers, O.M.; Else, T.; Baudin, E.; Berruti, A.; de Krijger, R.; Haak, H.R.; Mihai, R.; Assie, G.; Terzolo, M. European Society of Endocrinology Clinical Practice Guidelines on the management of adrenocortical carcinoma in adults, in collaboration with the European Network for the Study of Adrenal Tumors. Eur. J. Endocrinol. 2018, 179, G1-G46. [CrossRef] [PubMed]

4. Terzolo, M.; Angeli, A.; Fassnacht, M.; Daffara, F.; Tauchmanova, L.; Conton, P.A.; Rossetto, R.; Buci, L.; Sperone, P.; Grossrubatscher, E.; et al. Adjuvant mitotane treatment for adrenocortical carcinoma. N. Engl. J. Med. 2007, 356, 2372-2380. [CrossRef]

5. Calabrese, A.; Basile, V.; Puglisi, S.; Perotti, P.; Pia, A.; Saba, L.; Berchialla, P.; Porpiglia, F.; Veltri, A.; Volante, M.; et al. Adjuvant mitotane therapy is beneficial in non-metastatic adrenocortical carcinoma at high risk of recurrence. Eur. J. Endocrinol. 2019, 180, 387-396. [CrossRef]

6. Puglisi, S.; Perotti, P.; Cosentini, D.; Roca, E.; Basile, V.; Berruti, A.; Terzolo, M. Decision-making for adrenocortical carcinoma: Surgical, systemic, and endocrine management options. Expert Rev. Anticancer. Ther. 2018, 18, 1125-1133. [CrossRef]

7. Tornblom, N. Administration of DDD (2,2-bis (parachlorophenyl)-1,1-dichloroethane) to diabetics with hyaline vascular changes and hyperpolysaccharidemia. Acta Med. Scand. 1959, 164, 23-37. [CrossRef]

8. Young, R.B.; Bryson, M.J.; Sweat, M.L.; Street, J.C. Complexing of DDT and o, p $^{\prime}$ DDD with adrenal cytochrome P-450 hydroxylating systems. J. Steroid Biochem. 1973, 4, 585-591. [CrossRef]

9. Puglisi, S.; Perotti, P.; Pia, A.; Reimondo, G.; Terzolo, M. Adrenocortical Carcinoma with Hypercortisolism. Endocrinol. Metab. Clin. N. Am. 2018, 47, 395-407. [CrossRef]

10. Berruti, A.; Baudin, E.; Gelderblom, H.; Haak, H.R.; Porpiglia, F.; Fassnacht, M.; Pentheroudakis, G.; Group, E.G.W. Adrenal cancer: ESMO Clinical Practice Guidelines for diagnosis, treatment and follow-up. Ann. Oncol. 2012, 23 (Suppl. 7), vii131-vii138. [CrossRef] 
11. Hermsen, I.G.; Fassnacht, M.; Terzolo, M.; Houterman, S.; den Hartigh, J.; Leboulleux, S.; Daffara, F.; Berruti, A.; Chadarevian, R.; Schlumberger, M.; et al. Plasma concentrations of o, $\mathrm{p}^{\prime} \mathrm{DDD}, \mathrm{o}, \mathrm{p}^{\prime} \mathrm{DDA}$, and $\mathrm{o}, \mathrm{p}^{\prime} \mathrm{DDE}$ as predictors of tumor response to mitotane in adrenocortical carcinoma: Results of a retrospective ENS@T multicenter study. J. Clin. Endocrinol. Metab. 2011, 96, 1844-1851. [CrossRef]

12. Megerle, F.; Herrmann, W.; Schloetelburg, W.; Ronchi, C.L.; Pulzer, A.; Quinkler, M.; Beuschlein, F.; Hahner, S.; Kroiss, M.; Fassnacht, M.; et al. Mitotane Monotherapy in Patients With Advanced Adrenocortical Carcinoma. J. Clin. Endocrinol. Metab. 2018, 103, 1686-1695. [CrossRef]

13. Terzolo, M.; Baudin, A.E.; Ardito, A.; Kroiss, M.; Leboulleux, S.; Daffara, F.; Perotti, P.; Feelders, R.A.; deVries, J.H.; Zaggia, B.; et al. Mitotane levels predict the outcome of patients with adrenocortical carcinoma treated adjuvantly following radical resection. Eur. J. Endocrinol. 2013, 169, 263-270. [CrossRef]

14. Terzolo, M.; Pia, A.; Berruti, A.; Osella, G.; Alì, A.; Carbone, V.; Testa, E.; Dogliotti, L.; Angeli, A. Low-dose monitored mitotane treatment achieves the therapeutic range with manageable side effects in patients with adrenocortical cancer. J. Clin. Endocrinol. Metab. 2000, 85, 2234-2238. [CrossRef]

15. D'Avolio, A.; De Francia, S.; Basile, V.; Cusato, J.; De Martino, F.; Pirro, E.; Piccione, F.; Ardito, A.; Zaggia, B.; Volante, M.; et al Influence of the CYP2B6 polymorphism on the pharmacokinetics of mitotane. Pharm. Genom. 2013, 23, 293-300. [CrossRef]

16. Cusato, J.; De Francia, S.; Allegra, S.; Carrella, S.; Pirro, E.; Piccione, F.M.; De Martino, F.; Ferrero, A.; Daffara, F.C.; Terzolo, M.; et al. Circannual variation of mitotane and its metabolites plasma levels in patients with adrenocortical carcinoma. J. Pharm. Pharmacol. 2017, 69, 1524-1530. [CrossRef]

17. Ronchi, C.L.; Sbiera, S.; Volante, M.; Steinhauer, S.; Scott-Wild, V.; Altieri, B.; Kroiss, M.; Bala, M.; Papotti, M.; Deutschbein, T.; et al. CYP2W1 is highly expressed in adrenal glands and is positively associated with the response to mitotane in adrenocortical carcinoma. PLoS ONE 2014, 9, e105855. [CrossRef]

18. Puglisi, S.; Calabrese, A.; Basile, V.; Ceccato, F.; Scaroni, C.; Simeoli, C.; Torlontano, M.; Cannavò, S.; Arnaldi, G.; Stigliano, A.; et al Mitotane Concentrations Influence the Risk of Recurrence in Adrenocortical Carcinoma Patients on Adjuvant Treatment. J. Clin. Med. 2019, 8, 1850. [CrossRef]

19. Anderson, G.D. Gender differences in pharmacological response. Int. Rev. Neurobiol. 2008, 83, 1-10. [CrossRef]

20. Weiss, L.M.; Medeiros, L.J.; Vickery, A.L. Pathologic features of prognostic significance in adrenocortical carcinoma. Am. J. Surg. Pathol. 1989, 13, 202-206. [CrossRef]

21. Terzolo, M.; Ardito, A.; Zaggia, B.; Laino, F.; Germano, A.; De Francia, S.; Daffara, F.; Berruti, A. Management of adjuvant mitotane therapy following resection of adrenal cancer. Endocrine 2012, 42, 521-525. [CrossRef]

22. Fassnacht, M.; Johanssen, S.; Quinkler, M.; Bucsky, P.; Willenberg, H.S.; Beuschlein, F.; Terzolo, M.; Mueller, H.H.; Hahner, S.; Allolio, B.; et al. Limited prognostic value of the 2004 International Union Against Cancer staging classification for adrenocortical carcinoma: Proposal for a Revised TNM Classification. Cancer 2009, 115, 243-250. [CrossRef]

23. De Francia, S.; Pirro, E.; Zappia, F.; De Martino, F.; Sprio, A.E.; Daffara, F.; Terzolo, M.; Berruti, A.; Di Carlo, F.; Ghezzo, F. A new simple HPLC method for measuring mitotane and its two principal metabolites Tests in animals and mitotane-treated patients. J. Chromatogr. B 2006, 837, 69-75. [CrossRef]

24. Lane, J.R.; Connor, J.D. The influence of endogenous and exogenous sex hormones in adolescents with attention to oral contraceptives and anabolic steroids. J. Adolesc. Health 1994, 15, 630-634. [CrossRef]

25. Parish, R.C.; Spivey, C. Influence of menstrual cycle phase on serum concentrations of alpha 1-acid glycoprotein. Br. J. Clin. Pharmacol. 1991, 31, 197-199. [CrossRef]

26. Flores Pérez, J.; Juárez Olguín, H.; Flores Pérez, C.; Pérez Guillé, G.; Guillé Pérez, A.; Camacho Vieyra, A.; Toledo López, A.; Carrasco Portugal, M.; Lares Asseff, I. Effects of gender and phase of the menstrual cycle on the kinetics of ranitidine in healthy volunteers. Chronobiol. Int. 2003, 20, 485-494.

27. Wilson, J.T. Developmental pharmacology: A review of its application to clinical and basic science. Annu. Rev. Pharmacol. 1972, 12, 423-457. [CrossRef]

28. Blackham, A.; Spencer, P.S. The effects of oestrogens and progestins on the response of mice to barbiturates. Br. J. Pharmacol. 1969, 37, 129-139. [CrossRef]

29. Keskin, S.; Taş, F.; Vatansever, S. Adrenocortical carcinoma: Clinicopathological features, prognostic factors and outcome. Urol Int. 2013, 90, 435-438. [CrossRef]

30. Luton, J.P.; Cerdas, S.; Billaud, L.; Thomas, G.; Guilhaume, B.; Bertagna, X.; Laudat, M.H.; Louvel, A.; Chapuis, Y.; Blondeau, P. Clinical features of adrenocortical carcinoma, prognostic factors, and the effect of mitotane therapy. N. Engl. J. Med. 1990, 322, 1195-1201. [CrossRef]

31. Michalkiewicz, E.; Sandrini, R.; Figueiredo, B.; Miranda, E.C.; Caran, E.; Oliveira-Filho, A.G.; Marques, R.; Pianovski, M.A.; Lacerda, L.; Cristofani, L.M.; et al. Clinical and outcome characteristics of children with adrenocortical tumors: A report from the International Pediatric Adrenocortical Tumor Registry. J. Clin. Oncol. 2004, 22, 838-845. [CrossRef] [PubMed]

32. Huang, X.; Shu, C.; Chen, L.; Yao, B. Impact of sex, body mass index and initial pathologic diagnosis age on the incidence and prognosis of different types of cancer. Oncol. Rep. 2018, 40, 1359-1369. [CrossRef] [PubMed]

33. Rahane, C.S.; Kutzner, A.; Heese, K. Establishing a human adrenocortical carcinoma (ACC)-specific gene mutation signature. Cancer Genet. 2019, 230, 1-12. [CrossRef] [PubMed] 
34. Barzon, L.; Masi, G.; Pacenti, M.; Trevisan, M.; Fallo, F.; Remo, A.; Martignoni, G.; Montanaro, D.; Pezzi, V.; Palù, G. Expression of aromatase and estrogen receptors in human adrenocortical tumors. Virchows Arch. 2008, 452, 181-191. [CrossRef]

35. Felizola, S.J.; Nakamura, Y.; Hui, X.G.; Satoh, F.; Morimoto, R.; McNamara, K.M.; Midorikawa, S.; Suzuki, S.; Rainey, W.E.; Sasano, H. Estrogen-related receptor $\alpha$ in normal adrenal cortex and adrenocortical tumors: Involvement in development and oncogenesis. Mol. Cell. Endocrinol. 2013, 365, 207-211. [CrossRef]

36. Scollo, C.; Russo, M.; Trovato, M.A.; Sambataro, D.; Giuffrida, D.; Manusia, M.; Sapuppo, G.; Malandrino, P.; Vigneri, R.; Pellegriti, G. Prognostic Factors for Adrenocortical Carcinoma Outcomes. Front. Endocrinol. (Lausanne) 2016, 7, 99. [CrossRef]

37. Sirianni, R.; Zolea, F.; Chimento, A.; Ruggiero, C.; Cerquetti, L.; Fallo, F.; Pilon, C.; Arnaldi, G.; Carpinelli, G.; Stigliano, A.; et al. Targeting estrogen receptor- $\alpha$ reduces adrenocortical cancer (ACC) cell growth in vitro and in vivo: Potential therapeutic role of selective estrogen receptor modulators (SERMs) for ACC treatment. J. Clin. Endocrinol. Metab. 2012, 97, E2238-E2250. [CrossRef]

38. Wajchenberg, B.L.; Albergaria Pereira, M.A.; Medonca, B.B.; Latronico, A.C.; Campos Carneiro, P.; Alves, V.A.; Zerbini, M.C.; Liberman, B.; Carlos Gomes, G.; Kirschner, M.A. Adrenocortical carcinoma: Clinical and laboratory observations. Cancer 2000, 88, 711-736. [CrossRef]

39. Abiven, G.; Coste, J.; Groussin, L.; Anract, P.; Tissier, F.; Legmann, P.; Dousset, B.; Bertagna, X.; Bertherat, J. Clinical and biological features in the prognosis of adrenocortical cancer: Poor outcome of cortisol-secreting tumors in a series of 202 consecutive patients. J. Clin. Endocrinol. Metab. 2006, 91, 2650-2655. [CrossRef]

40. Zheng, S.; Cherniack, A.D.; Dewal, N.; Moffitt, R.A.; Danilova, L.; Murray, B.A.; Lerario, A.M.; Else, T.; Knijnenburg, T.A.; Ciriello, G.; et al. Comprehensive Pan-Genomic Characterization of Adrenocortical Carcinoma. Cancer Cell 2016, 30, 363. [CrossRef] 